\title{
The Image of Makassar Women in Natisha Persembahan Terakhir by Khrisna Pabichara
}

\author{
Bulan Rara Yangsen, Inriati Lewa, Muhammad Syafri Badaruddin \\ Faculty of Cultural Sciences - Hasanuddin University, Makassar, South Sulawesi, Indonesia
}

\begin{abstract}
This study aims to reveal the image of Makassar women contained in the novel entitled Natisha Persembahan Terakhir (NTA). The data collection method used in this research is the literature study. The data analysis method in this study is qualitative descriptive in manner. The data presented are regarding the image of Makassar women contained in the NTA by Khrisna Pabichara. The results showed that the image of Makassar women was seen in two domains, namely the domestic sphere and the public sphere. In the domestic sphere, it is characterized by women staying at home, women being obedient and emotional, women choosing partners, and women in the household. The image of Makassar women in the public sphere is marked by women in education and women in society.
\end{abstract}

Keywords: image, women, novel, literary structural theory, woman voice.

\section{INTRODUCTION}

$\mathrm{W}$ omen with all their positions and existences have always been an interesting discussion and never ended. This can be seen from the many studies on women's issues than men. In essence, women and men have the same status in society. What distinguishes them is the function and role they carry in dealing with life's problems.

The Makassar tribe is one of the ethnic groups in South Sulawesi whose dynamics in the lives of women and men can be traced to this day. The position of women can be seen from various studies on patterns of gender relations, both in lontara, writings about women, folklore, or history.

Makassar ethnic society views women in life as baine. The mention of baine comes from the word bine which means seed or forerunner, so it can be interpreted as the origin or beginning. The Makassar tribal society places women as the pinnacle of dignity which is not only a symbol but also the essence of a marker of degree and dignity in a family.

Records of Makassar women in the written or oral tradition began during the formation of the Gowa Kingdom regarding the story of the presence of "To Manurung Bainea". The history of the manuscript about To Manurung Bainea version of the Ancient Lontaraq of Gowa tells of a beautiful woman wearing Makassar's oversized clothes that came down from the sky, then named To Manurung Baine or To Manurunga. The woman was the answer to the prayers of the people of Gowa at that time who longed for a new leader because of the failure of the previous leader, namely Paccalla. Paccalla's leadership of nine groups of people in Gowa is considered a failure because the people experience misery, and are constantly hit by civil war between North Gowa and South Gowa. The presence of To Manurung made the hopes of the people of Gowa seem to come true, so they agreed to appoint him as a leader. In contrast to Pacalla, under the reign of To Manurung, there was a sense of security created by all the people as seen from the union of small kingdoms and then joining the big kingdom, namely the kingdom of Gowa, which was also a symbol of royal unity at that time. This indicates that women at a certain time, especially Makassar women, can become a symbol of leadership as a unifier of the people who are in a divided condition and the giver of the spirit of peace[1].

In addition to the story of To Manurung Bainea above, the image of Makassar women can also be seen from historical records which prove that Makassar women took part in the struggle against the invaders. One of these female figures is I Fatima Daeng Takontu Karaeng Campagaya, daughter of Sultan Hasanuddin. Fatima helped the struggle against the Dutch by becoming the leader of the Bainea Troops (Women's Troops), joining the forces of Sheikh Yusuf. He was later given the title "Garuda of the East" by a Dutch poet because of his persistence and expertise in martial arts[1].

Apart from historical aspects and cultural values, the image of Makassar women can also be seen from the linguistic aspect which refers to expressions about women, especially in the role of "mothers". This can be seen in the use of the words ammaq and anrong.

The use of the word ammaq refers to a mother as a human being, in this case, it is a denotative meaning, while anrong is used more broadly and has a connotative meaning as in the expression anrong lima (thumb), or anrongrante (liontin)[1]. These expressions, of course, have a deep meaning for the people of Makassar regarding the image, position, and existence of women in the context of Makassar culture.

When viewed from the reflection of the life of the Makassar tribal community through the literature review above, it can be said that Makassar women have positive and respectable indications, both in terms of status, position, role, or function in society. Women have the same potential as men, and on various occasions, women do not only take part in the domestic sphere but also in the public sphere. In this case, women have full freedom individually in thinking and acting rationally because essentially women have the same rights and opportunities as men. This refers to the strength and power 
that women have within themselves, other than that what is not spared is the availability of space and opportunities for women to make women able to express the qualities that they have.

The issue of inequality against women still often occurs in various aspects of life. In the midst of their struggles, women have never been separated from issues and treatments which illustrate those women are still in a condition of being excluded, marginalized, and left behind both economically, politically, and socially. Gender issues are one of the most important factors in society because they can lead to conflict and social change. The concept of gender is an inherent trait of men and women who are reconstructed socially and culturally [2].

The nature attached to women and men in the concept of gender, for example, that women are known to be gentle, feminine, emotional, or motherly, while men are considered firm, rational, tough, intelligent, manly, and mighty. The images of these properties are interchangeable properties. That is, some men are emotional, gentle, motherly, and some women are strong, rational, and mighty. Changes in the characteristics of these properties occur from time to time, and from one place to another. All things that can be exchanged between the nature of women and men, which can change from time to time and differ from one place to another which is what is known as the concept of gender [2].

The deeply rooted nature of women and men leads to the formation of a mindset in the society. This nature gives rise to gender discourse, namely the strong dominate and the weak are subordinated. However, in reality, women are still placed lower than men. Women occupy an unfavorable position and do not have the freedom to live their lives, often experience exploitation, oppression, and so on. The influence of this constructed system synergizes with the relations between men and women, as well as women and fellow women in society.

The issue of gender then spreads into literary discourses. Literary works as one of the media manifestations of society do not exist from a mere emptiness. Authors in creating literary works will be influenced by the socio-cultural background that surrounds them. Values in literary works are the result of a combination of expressions [3] and literary creations adapted from the culture of the people[4]. In this case, the patriarchal system that develops in society makes literary works an imaginative world written by authors that cannot be separated from gender issues.

The world of literature is dominated by men, meaning that literary works are as if intended for male readers. Even if there is a female reader, she is forced to read as a man [5]. Patriarchal culture is an embodiment of the ideology of hegemony which assumes that men are the authority and women are the second sex, second-class citizens, and are subordinated. Male figures are generally depicted as stronger and have authority over women. This happens and can be seen in almost all literary works, both works created by male and female writers.

Several things can be seen regarding the dominance of men over women which also influence the condition of literature, including 1) Literary values and conventions are still dominated by male power, 2) Women in literary works are still dominated by men. in the stage of continuous struggle towards gender equality, 3) Male writers generally tend to give judgments that are not objective and even one-sided. Women are always depicted as gentle, submissive, their opinions are not heard, and become objects of pleasure for men. While men are described as independent, firm, and can have more dominance over women, and 4) Women in literature are always considered as literary flowers.

Natisha's NPT is one of Pabichara's novels published in May 2016 with a Makassar cultural background. Complexly, this novel discusses various kinds of issues such as socio-cultural, political, mystical, and the struggle of love with local wisdom presented by the author[6].

In the NPT novel, Khrisna displays the image of women, especially Makassar women, according to the background of the NPT novel, Makassar. This emphasizes the opinion of Abrams[7] that the setting or setting in a literary work is referred to as the fulcrum, suggesting the notion of place, time relationship, and the social environment in which the events are told.

The existence of women in various aspects in the novel cannot be separated from various gender issues. Forms of gender injustice, namely stereotypes, violence, exploitation, and even discrimination make women in an inferior position, oppressed, and have no freedom over their lives. This study uses Robert Stanton's structural theory to understand the existence of women through the images displayed in the novel, both the image of Makassar women in the domestic sphere and in the public sphere. The image displayed expresses the depiction of men and women in terms of equal rights and opportunities, division of labor, marriage, and education. The image will be seen from the texts displayed in the novel through its intrinsic and extrinsic elements.

Judging from the title, Natisha Persembahan Terakhir, this novel features a female character named Natisha by the author. Nastiha has noble names, namely Daeng Lebang, and Karaeng Marannu which were given by Natisha's father as a marker of social strata status in the novel, as well as a marker of the setting and setting of the atmosphere. The phrase "last offering" means that Natisha is the last offering in a ritual performed by the figure of Rangka. Referring to the last offering phrase shows that there was an initial offering made by Rangka. The offering also sacrifices other female characters in the novel.

This research will use Stanton's theory of literary structuralism. Character, plot, and setting are the facts of the story[8]. These elements serve as a record of the imaginative 
events of a story[9]. If summarized into one, all these elements are called factual structure or factual level of the story. The factual structure is a story that is highlighted from one point of view[8].

A plot is a series of events in a story. The term plot is usually limited to causally connected events which are events that cause or result from various other events and cannot be ignored because they affect the entire work. The setting is the environment that surrounds an event in the story, the universe that interacts with ongoing events. Setting can also be in the form of certain times of day, month and year, weather, or a historical period.

Characters are usually used in two contexts. In the first context, a character refers to the individuals who appear in the story. In the second context, a character refers to the mixture of various interests, desires, emotions, and moral principles of these individuals (Rahman[10]; Stanton [8]).

Character is one of the important elements in a novel. Characters have different characteristics that give birth to a variety of behavior and their respective stories. Characters present in front of the reader carry certain qualifications, especially regarding identity. Actors who carry events in fictional stories so that the events are able to weave a story are called characters[11]. Jones in Nurgiyantoro[12] states, characterization is the depiction of a clear picture of a person displayed in a story. In other words, characterization is the way the author characterizes the character.

\section{THE SKETCH OF THE WORK}

This work tells the story of a Makassar noble daughter named Natisha running away with Rangka the day before her wedding to Tutu, her lover. Rangka is an adherent of parakang, an ancient magic that can make its adherents rich, youthful, and immune to all kinds of weapons. Due to magic, Natisha is lured to leave her future husband. For the sake of the perfection of his knowledge, Order must present 4 women: 2 have given birth, 2 are still virgins The nature of each offering must be in harmony with the 4 natures of the natural elements according to the rituals he undergoes: Water, Earth, Fire, Wind. And the lively Natisha will be the final offering. The human transformed into a wolf, who sings ancient hymns, has welcomed the drops of Natisha's virgin blood!

However, before that happens, through a secret message found in the attic of Rangka's house, Tutu then tries to crack the secret codes in the ancient book on parakang, in order to fight Rangka and reclaim Natisha.

Compiled from the treasures of tradition, presented in indescribable narratives, this novel will hypnotize you to walk down dark alleys in one corner of the archipelago, ready to shock you at how thin the difference between love and anger is.

\section{STUDY OBJECTIVES}

The purpose of this study is to reveal the image of Makassar women contained in the Novel Natisha Permbahan Akhir by KhrisnaPabichara both in the domestic sphere and in the public sphere. The strategy to achieve this goal is to present data in the form of fragments of text related to the research topic.

\section{METHODOLOGY}

The method used in this study is a qualitative descriptive method with an orientation in the form of interpretation of literary texts as seen from the intrinsic elements of literary works such as characters and characterizations, plot, setting, and so on. From the intrinsic aspect, it is then continued by revealing the extrinsic aspect to obtain a unified whole meaning.

The primary data in this study are data in the form of words, sentences, or paragraphs that have a direct relationship with the image of Makassar women contained in the novel NPT by Khrisna Pabichara. Secondary data is objective and complete data that is generally obtained from various readings that support research and relate to the issues discussed. The data collection technique used in this research is library research or is called content analysis.

\section{FINDING AND DISCUSSION}

In the novel, Natisha Persembahan Terakhir (NPT), forms of gender inequality result in women experiencing injustice. The forms of inequality are in the form of violence and stereotypes. The treatment of male characters towards female characters is sole because of the gender construction that continues to be associated with various existing motives. This inequality gives an illustration of the image of Makassar women shown in the novel. Inequality is always something that can be analyzed when men and women are placed in public and domestic spaces.

\subsection{The Image of Makassar Women in the Domestic Area}

\subsubsection{Woman Stay at Home}

Women are always associated with domestic affairs because of the social construction that governs them in such a way and this happens in this novel. In the novel NPT, generally, the image of Makassar women has depicted those women are more at home than working outside the home. Women spend more time waiting for their husbands without doing any activities. This can be seen from the following quote.

\section{Fragment 1}

"Di kampungku, siang sangatlah sepi. Para lelaki lebih banyak di kebun, kaum perempuan lebih suka berdiam diri di rumah atau tidur-tiduran di balaibalai kolong rumah"

("In my village, it is very quiet during the day. The men are more in the garden, the women prefer to 
stay at home or sleep in the halls under the house")

(Pabichara, 2016:5).

The quote above illustrates the division of labor between men and women. Men are depicted as busy working the fields, while women are mostly at home and sleeping. This was conveyed by the Tutu figure when Tutu was on his way to meet Daeng Saleng. The quote above indirectly describes women who are identified with home and laziness so that women only rely on men to work in the fields.

\subsubsection{Woman in Obedient and Emotional}

The obedience attached to women comes from the understanding that women are only able to accept all perceptions and views of men. Women are identified with excessive emotions when facing cases so that women can only surrender and accept everything, even though their hearts do not fully accept them. The quote below describes Natisha who is only able to cry when her opinion is not heard by Tutu, her fiancé.

\section{Fragment 2}

"Natisha mengurung diri di kamarnya. Dia menolak menemuiku. Hanya isak tangis dan gerutuan yang kudengar dari balik pintu kamarnya. Tidak jelas apa yang diagerutukan"

("Natisha locked herself in her room. She refused to see me. I only heard sobs and groans from behind her bedroom door. It is not clear what she was grumbling about")

(Pabichara, 2016:94).

Tutu is challenged by Rangka to do an abatte match in front of a crowd. Abatte is self-defense that has now turned into a free fight. This tactic has been prepared by Framework from the previous days. Rangka and Tutu are best friends, but it turns out that Rangka has a lot of envy and hatred for Tutu in his heart. Rangka intends to harm Tutu because of the grudge, as well as to cancel Tutu and Natisha's marriage. The order has even prepared a sharp weapon, namely badi' to launch the action. Natisha had a bad feeling that this was not good, especially the next day they were getting married. However, Rangka continues to provoke Tutu in front of the crowd to accept Rangka's challenge. Tutu then accepted the challenge with the excuse of siri' and to show his existence in front of the crowd.

The thing that can't be denied for Natisha is howling when her fiancé wants to do a match that will endanger her own life even though the next day is their wedding day. When her opinion was ignored by Tutu, there was no other way for Natisha but to mourn her grief

\subsubsection{Women in Choosing a Partner}

The NPT novel is a novel that presents a depiction of Makassar women, especially in the Turatea area with the surrounding customs. Women's lives are regulated in such a way in the domestic sphere, including in choosing a partner. In Turatea, society has a caste system that is formed and this is what directly or indirectly regulates the life that occurs.

\section{Fragment 3}

"Di Turatea, ada kasta yang tidak tersentuh. Karaeng namanya. Lelaki pada kasta tertinggi berhak menikahi gadis dari kasta mana saja, termasuk daeng dan ata. Namun, perempuannya tidak boleh dinikahi kasta di bawahnya"

("In Turatea, there is an untouchable caste. Karaeng's name. Men in the highest caste have the right to marry girls from any caste, including daeng and ata. However, women cannot be married by castes below them")

(Pabichara, 2016:90).

Furthermore, in another quote, it is mentioned that:

Fragment 4

"Ku pejamkan mata sejenak, lalu menggumam, "suatu saat aku harus memiliki gadis itu. Masa bodoh dia putr iseorang karaeng puli, Kasing. Masa bodoh kekayaan orangtuanya melebihi kekayaan Tuhan!"

("I closed my eyes for a moment, then mumbled, "Someday I have to have that girl. What a fool she is the daughter of a Karaeng Puli, Kasing. Foolishly, his parents' wealth exceeds God's wealth!')

(Pabichara, 2016:95).

Tutu's figure becomes worried when his good intentions to approach Natisha are not responded to well by Natisha's family. Natisha's father is a Karaeng Puli who is described as occupying the highest caste in the social strata formed in Turatea. Through the quote above, an image is given that women are always confined in all directions. There are no exceptions for women, ranging from high castes to low castes, women are arranged in such a way that they do not have the freedom to choose a partner. This is reaffirmed from the quote below.

\section{Fragment 5 \\ "Lebihjanggallagibila gadis darikalangan daeng dibawalari oleh pemuda karaeng, orangtua gadis ituakandenganmudahmenyatakanpenerimaan dan perelaankarena “darahbiru” si pemuda”}

("It's even odder when a girl from the daeng circle is taken away by a Karaeng youth, the girl's parents will easily express acceptance and acceptance because of the young man's "blue blood" ")

(Pabichara, 2016:94). 
The Tutu figure in this quote tries to describe the condition of women in the traditional customs that occur in Turatea. Acceptance and rejection because of caste are unavoidable. In marriage, a woman's family will be observant of the caste of her potential partner.

\subsubsection{Women in Household}

The NPT novel shows the presence of women when they enter the household. Women as wives or as housewives carry out everything according to their respective roles. Various treatments from male characters as husbands cover the lives of women as wives. In the novel NPT, violence perpetrated by male characters against female characters is unavoidable.

The violence perpetrated by Rangka's character against several female characters in the novel is an attempt to show their existence. Skeleton is an adherent of parakang, an ancient science that is able to make its adherents rich, youthful, and immune from all kinds of weapons. For the sake of the perfection of his knowledge, Rangka offered four female victims as sacrifices, two of the four victims were his own wife. This violence is illustrated in the following quote.

\section{Fragment 6}

"Tiba-tibaa kumelihat seseorang, seperti
perempuan, berjalan terseok-seok, lalu jatuh
terentang. Sejurus kemudian ia merangkak di sela-
sela belukar. Pakaiannya basah kuyup. Rambut dan
wajahnya basah. Tetes-tetes air menggantung di
dagunya. Perempuan itu berhenti, menggigil
kedinginan, menangis, menciar-ciar bagai bayi
yang kehausan mencari payudarai bunya, lalu
berpaling kepadaku. Menjulur-julur tangannya
seperti meminta bantuan. Dia gelagapan, napasnya
megap-megap tingkahnya seperti orang tenggelam
menggerapai. Lehernya berdarah, lengannya
berdarah. Terserap rasa kasihan, aku berjalan
mendekatinya"

("Suddenly I saw someone, like a girl, staggering, then fell on her back. A moment later he crawled through the bushes. His clothes were soaking wet. His hair and face were wet. Drops of water hung down his chin. The woman stopped, shivering from the cold, crying, squirming like a thirsty baby looking for its mother's breast, then turned to me. He stretched out his hand as if asking for help. He was stuttering, his breath gasping for air, his behavior was like a drowning man. His neck was bleeding, his arms were bleeding. Absorbed in pity, I walked over to him")

(Pabichara, 2016:330).

The quote above tells the story of a woman named Daeng Caya. Daeng Caya is the first wife of Rangka's figure who is offered or sacrificed by Rangka. In the quote above, it is told about Tutu who saw the spirit of Daeng Caya in a pathetic condition. The spirit appeared to Tutu who happened to have a sixth sense. Rangka kills Daeng Caya in a tragic way. Rangka's treatment of his wife can be seen in the quote below.

$$
\begin{aligned}
& \text { Fragment } 7 \\
& \text { “akutenggelam di danau," katanya. } \\
& \text { “akusengajaditenggelamkan." } \\
& \text { "siapa yang membunuhmu?" tanyakulagi. } \\
& \text { "suamiku sendiri." }
\end{aligned}
$$

("I drowned in the lake," he said.

"I was deliberately drowned."

"Who killed you?" I asked again.

"my own husband.")

(Pabichara, 2016:330).

The quote above explains that the character Rangka is willing to kill his own wife cruelly, by drowning her in a lake. This was solely done by Rangka because he believed in the ancient thing, namely parakang to achieve the perfection of life.

\subsection{The Image of Makassar Women in Public}

The image of women in the public sphere can be seen from the position of women when they are outside the home. The treatment of male characters to female characters in public or in public will give women a description of their existence. The image is a social image that discusses the space and opportunity for women to explore the knowledge that women have, the opportunities available to women, and other things.

\subsubsection{Woman in Education}

Education is one of the most important things for women. In the novel NPT, a Makassar woman is represented by Natisha, who is so enthusiastic about the education she is taking. However, gender construction results in women not getting the same space and opportunities as men on various occasions. Women are often subordinated and not appreciated in all their achievements. This can be seen in the following.

\section{Fragment 8}

"Satu demi satu peserta lomba pidato tampil. Belum ada peserta yang penampilannya memikat. Hingga tibalah giliran Natisha. Gadis dengan tiga nama itu tampil sangat tenang. Dia membuat peserta lain melongo dan ternganga. Dewan juri juga terkesima. Padahal biasa saja"

("One by one the speech contest participants appeared. There is no participant whose appearance is attractive. Until it was Natisha's turn. The girl with three names appeared very calm. He made the other participants gape and gape. The jury was also amazed. Even though it's normal") 
(Pabichara, 2016:143).

During their school days, Natisha and Tutu were outstanding students in their respective schools. The quote above describes the atmosphere of the competition they participated in. At that time, Tutu and Natisha became representatives of their respective schools. The quote above describes how Natisha is able to explore her knowledge and qualities in public. This illustrates how women are so enthusiastic about education. However, his effforts and achievements to show his existence in public or in front of many people are often not appreciated. Women often do not receive respect and are not fully appreciated by men. The image of women in education can also be seen in the quote below.

Fragment 9

"Mereka sudah bertunangan. Tinggal tunggu waktu, mereka menikah. Rencananya Laila ingin menyelesaikan kuliahnya dulu. Dia ingin menjadi peraih gelar doktor termuda di Jeneponto"

("They are engaged. It's just a matter of time, they get married. Laila plans to finish her studies first. He wants to be the youngest doctoral recipient in Jeneponto")

The quote above describes the character Tutu who expresses the enthusiasm of women in pursuing their education. Laila is one of the female figures who also received violent treatment from Rangka. The enthusiasm of women to have a higher education is illustrated by Tutu's statement above. This concludes that in the public sphere, women continue to fight for their quality to be recognized by the community.

\subsubsection{Women in Society}

Natisha's novel describes the existence of Makassar women in society. This novel clearly places women as the essence of status markers in the family. Behind that, labeling women in various ways is also unavoidable. This can be seen in the quote below:

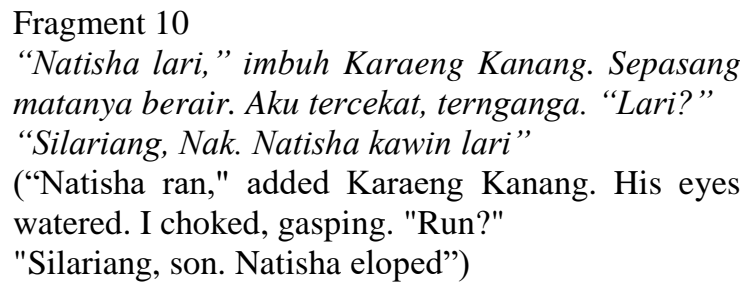

(Pabichara, 2016:143).

The quote above reaffirms that the existence of women as the essence of status markers in the family has a double moral burden in society. In her perspective, Makassar women, with labels attached to them, will be accused of being the main culprits in problems that occur because of gender construction and this is discrimination against women. The reality in the novel is that Natisha was kidnapped by Rangka, but due to gender construction, rumors spread throughout the village that Natisha silariang. This was revealed by Natisha's parents in front of many people as a sign that in society, women are often associated with irrational negative events and are easily labeled as the culprits of these problems. In the novel NPT, it is described that the treatment of male characters towards female characters is the initial source or trigger for the negative labeling of women. In addition to the multiplied moral burden, demands on women are also unavoidable in society. Furthermore, the perception of rationality and being able to take care of themselves in the midst of subordination and discrimination is something that women must do. This is reiterated in the following.

\section{Fragment 12}

"Baiklah, sebu tsaja Natisha terpaksa pergi karena dia sebatas menjalani takdir yang digariskan Tuhan, tapi ia bisa saja berusaha melawan takdir. Kenyataannya, tidak! Natisha tetap pergi dan kamu, juga keluarganya, menanggung malu"

("Well, let's say Natisha was forced to leave because she was limited to living the destiny that God had outlined, but she could try to fight fate. In fact, no! Natisha still goes and you, as well as her family, bear the shame")

(Pabichara, 2016:49).

The sign that Natisha was kidnapped became clearer when a letter was found in her room after Natisha went missing. The letter was written by Rangka and made it clear that Natisha's kidnapping was planned. Skeletons that have supernatural powers influence Natisha's mind to go with her. The quote above, indirectly illustrates those women are always required in every way to behave well in accordance with existing values. When women are beyond their capabilities to do things that conflict with these values, often negative responses are then present without knowing the cause of the problem.

\section{CONCLUSION}

Based on the results of research on the Novel NPT by Khrisna Pabichara some conclusions are as follows: 1) The NPT novel is a novel that describes the role and position of Makassar women, especially in the Turatea area, 2) Makassar women experience many injustices caused by the patriarchal system and gender construction, and 3). This system has an effect on the image of women shown in NPT.

This finding is based on structural analysis using Robert Stanton's theory of structuralism. The image of women in this novel is seen in the domestic and public spheres. The results showed that the image of Makassar women in Khrisna Pabichara's novel NPT was characterized by women staying at home, obedient and emotional women, women in choosing partners, and women in the household, while the image of 
Makassar women in the public sphere was marked by women in education and women in society.

The implications of this research are expected to be able to enrich insight into the image of women in society and the culture represented in literary works. In addition, this research is expected to be material for readers to consider in order to analyze the novel further regarding the images of women in the novel in an effort to gender equality.

\section{REFERENCES}

[1] E. Iswary, Perempuan Makassar Relasi Gender dalam Folklor. Yogyakarta: PEnerbit Ombak, 2010.

[2] M. Fakih, Analisis Gender \& Transformasi Sosial. Yogyakarta: Pustaka Pelajar, 2021.

[3] F. Rahman, "Literature of the Minority in South Sulawesi Endangered," Soc. Sci. Medwell Journals, vol. 13, no. 4, pp. 820825, 2018, doi: 10.36478/sscience.2018.820.825.
[4] Sugiarti, Pembangunan dalam Perspektif Gender. Malang: UMM Press, 2008.

[5] S. \& Suharto., Kritik Sastra Feminisme Teori dan Aplikasinya. Yogyakarta: Pustaka Pelajar, 2016.

[6] K. Pabichara, Natisha Persembahan Terakhir. Banten: PT Kaurama Buana Antara, 2016.

[7] M. H. Abrams, Teori Pengantar Fiksi. Yogyakarta: Hanindita, 1981.

[8] R. Stanton, Fiction Theory (Diterjemahkan oleh Sugihastuti dan Rossi Abi Al Irsyad). Yogyakarta: Pustaka Pelajar, 2007.

[9] F. Rahman, "Literature in language teaching: The strategy of teaching literature for Non Native of English Students," OSF Prepr., 2020, [Online]. Available: https://osf.io/6xm4z.

[10] F. Rahman, "The Revival of Local Fairy Tales for Children Education," Theory Pract. Lang. Stud., vol. 7, no. 5, p. 336, 2017, doi: 10.17507/tpls.0705.02.

[11] Aminudin, Pengantar Apresiasi Karya Sastra. Bandung: Sinar Baru Agesindo, 2004.

[12] B. Nurgiyantoro, Teori Pengkajian Fiksi. Yogyakarta: Gajah Mada University Press, 2015. 